\title{
Evaluation of complete blood count in bitches with ovarian tumors: A preliminary study
}

\author{
Tuğba Çoban ${ }^{1}$, Zeynep Günay Uçmak ${ }^{2^{*}}$, Mehmet Ragıp Kılıçarslan ${ }^{2}$, Özge Erdoğan \\ Bamaç $^{3}$
}

Research Article

Volume: 5, Issue: 1

April 2021

Pages: $1-5$

\section{Article History}

Received: 07.12.2020

Accepted: 26.01.2021

Available online:

03.3.2021
1. Institute of Postgraduate Education, Istanbul University-Cerrahpaşa, Istanbul, Turkey. 2. Department of Obstetrics and Gynaecology, Faculty of Veterinary Medicine, Istanbul University-Cerrahpaşa, Istanbul, Turkey. 3. Department of Pathology, Faculty of Veterinary Medicine, Istanbul University-Cerrahpaşa, Istanbul, Turkey. Çoban, T. ORCID: 0000-0003-4129-7720, Günay Uçmak, Z. ORCID: 0000-00032530-1291, Kılıçarslan, M. R. ORCID: 0000-0003-3412-766X, Erdoğan Bamaç, Ö: ORCID: 00000002-0352-4841.

\begin{abstract}
Ovarian tumors are rarely seen in bitches and they usually occur in older ages. The most common type of ovarian tumor is epithelial tumors. Hematological parameters are frequently affected by the presence of neoplasms. There are various types of anemia associated with neoplasms. In the present study; we investigated the relationship between complete blood count $(\mathrm{CBC})$ and the presence of ovarian tumors in bitches. Seven bitches with ovarian tumors and 6 bitches with histologically healthy ovaries were selected for this study. Increased level of platelet (PLT) was determined in bitches with ovarian tumors and considered as a significant finding to estimate the cancer progression. Besides, red blood cells (RBC), hematocrit (HCT), and hemoglobin (HGB) levels were decreased in bitches with ovarian tumors, which might be associated with cancer related anemia. In conclusion, the evaluation of complete blood count in bitches with ovarian tumors can be important to estimate the hematological effect of tumor progression.
\end{abstract}

Keywords: dogs, ovary, neoplasm, thrombocytosis, anemia

DOI: https://doi.org/10.30704/http-www-jivs-net.837033

To cite this article: Çoban,T., Günay Uçmak, Z., Kılıçarslan, M. R., Erdoğan Bamaç, Ö. (2021). Evaluation of complete blood count in bitches with ovarian tumors: A preliminary study. Journal of Istanbul Veterinary Sciences, 5(1), 1-5. Abbreviated Title: J. İstanbul vet. sci.

\section{Introduction}

Ovarian tumors are rarely seen in bitches due to neutralization at early ages (Gomez-Laguna et al., 2008). Ovarian neoplasms occur in a wide age range in bitches, but granulosa cell tumors (GCT) and teratomas appear at a younger age than others (DiezBru et al., 1998). Four main categories are defined for ovarian neoplasms; epithelial, germ cell tumors, sexcord stromal tumors and mesenchymal tumors. Epithelial tumors include papillary adenomas, papillary adenocarcinomas, rete adenomas and undifferentiated carcinomas. Epithelial tumors constitute $40 \%$ to $50 \%$ of all canine ovarian tumors (Bertazzolo et al., 2004). Papillary adenocarcinoma is a common type and often/frequently occurs bilaterally, similar to papillary adenoma (Nielsen et al., 1976). Germ cell tumors consist of dysgerminomas, ovarian teratomas and embryonal carcinomas. Sex-cord stromal tumors include granulosa cell tumors, luteomas and thecomatas (Bertazzolo et al., 2004). Luteoma is a less common tumor type that has limited reports in mares, cats and monkeys (Namazi et al., 2015). There is not much information about breed predisposition in dogs however Bulldog and Boxer breeds display the highest risk (Sforna et al., 2003).

The clinical observation in dogs with ovarian tumors is variable. Ovarian tumors can be detected by
*Corresponding Author: Zeynep Günay Uçmak E-mail: vethekzeynep86@gmail.com
Journal home page: www.jivs.net http://dergipark.gov.tr/http-www-jivs-net 
chance during the sterilization process. The most common clinical manifestation is peritoneal or pleural effusion. Prolonged pro-oestrus or oestrous (prolonging/extended more than a month) may also be associated with ovarian tumors (McEntee, 2002). It has been reported that ovarian tumors mostly arise at the left ovary. The recommended treatment for dogs with ovarian tumors is operative intervention (DiezBru et al., 1998).

The most common paraneoplastic syndrome in veterinary oncology is anemia (Aydın et al., 2011). Moreover, the amount of PLT was found to be higher in dogs with mammary tumors (Günay Uçmak and Güvenç, 2019). Correspondingly, this study aims to investigate changes in complete blood count (CBC) in dogs with ovarian tumors.

\section{Materials and Methods}

Animals and study design: Ethics approval for the study was obtained from the unit Ethics Committee (number: 2020/28). Thirteen intact bitches were enrolled in the study. All bitches were presented to the clinic of Obstetrics and Gynaecology for ovariohysterectomy. They were gynaecologically examined with B-mode real-time ultrasonography. The bitches were allocated into two groups according to histopathological examination of the ovaries. Group OT consisted of seven bitches with ovarian tumor and group $\mathrm{H}$ consisted of six bitches with histologically healthy ovaries. The groups were designed regardless of breed variation.

B-mode real-time ultrasonography: All bitches were checked with B-mode real-time ultrasonography (MyLab 5-Vet ESAOTE ${ }^{\circledR}$, Genova, Italy) using a microconvex probe of $6.5 \mathrm{MHz}$ via transabdominal route.

Determining the stage of oestrus: The stage of oestrus was determined by vaginal cytology. The samples were collected using cotton swab. Smears were stained with Diff Quick method according to manufacturers' instructions (Hemacolor ${ }^{\circledR}$ stain; Merck, Darmstadt, Germany). Vaginal epithelial cells were evaluated using a light microscope (BAB-LAM, BAB, Turkey) at X400 magnification.

Hematological examination: Blood samples were collected from all bitches for CBC. After asepsis and antisepsis was provided, $2 \mathrm{ml}$ blood samples were collected into etilendiamine tetraacetic acid
(EDTA) tubes from vena cephana parva of each bitches. Red blood cell (RBC, $M / \mu L)$, Hematocrit (HCT, \%), Hemoglobin (HGB, g/dL), White blood cell $(\mathrm{WBC}, \mathrm{K} / \mu \mathrm{L})$, Platelet $(\mathrm{PLT}, \mathrm{K} / \mu \mathrm{L})$, Plateletcrit (PCT, \%) were measured using hematology analyzer (ProCyte Dx, IDEXX Laboratories, USA).

Surgical intervention: The bitches were initially premedicated with atropine sulfate $(0.03 \mathrm{mg} / \mathrm{kg}$, sc) (Atropin ${ }^{\circledR}$, Teknovet, Turkey). For induction of the anesthesia $1 \%$ propofol (Lipuro $^{\circledR}$, Braun, England) was used at $4 \mathrm{mg} / \mathrm{kg}$, iv and $3 \%$ isoflurane (Forane liquid ${ }^{\circledR}$, Abbott Laboratories, England) and 0.5-1 \% oxygen combination was used to maintain the anesthesia. Median line was preferred for laparotomy incision. Absorbable suture materials (Monocryl No:0) were used for ligations and sutures in the ovariohysterectomy section.

Histopathological examination: Ovarian tissues were fixed in $10 \%$ neutral buffered formalin, paraffin embedded, sectioned at $4 \mu \mathrm{m}$, and stained with hematoxylin and eosin (HE) for histopathological examination by light microscopy.

Statistical analysis: The SPSS 13.0 packet program was used for the statistical analyses. Levene's test was performed to determine the equality of variances. Statistical difference in terms of RBC, HCT, HGB, WBC, PLT and PCT between the groups was investigated by $t$-test. The mean values and standard errors of the related parameters were determined.

\section{Results}

The mean age of bitches in group OT and group $\mathrm{H}$ were $10.43 \pm 1.87$ and $6.17 \pm 0.47$ years; respectively. The mean age of the bitches with ovarian tumors were tended to be higher but failed to reach significance $(P=0.06)$. All bitches in both groups were of different races. During the ultrasonography examination, enlargement of the affected ovaries was determined in bitches with granulosa cell tumor (GCT) $(6.1 \times 4.3 \mathrm{~cm})$, luteoma $(2.9 \times 3.6 \mathrm{~cm})$, papillary adenocarcinoma $(1.9 \times 1.8$ $\mathrm{cm}$ ) (Figure 1) while the other neoplastic ovaries in group OT could not be detected. The ovary sizes of the ovaries belong to the bitches in group $\mathrm{H}$ were in normal ranges. After ovariohysterectomy section was performed, the 


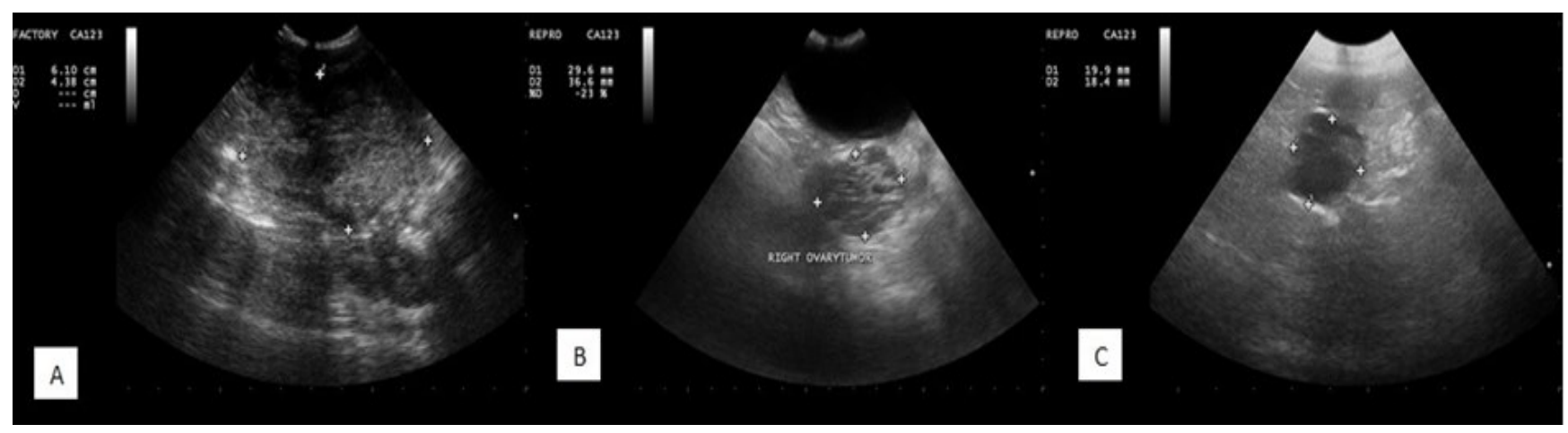

Figure 1. B- mode real time ultrasonography images in bitches with ovarian tumor A: Granulosa cell tumor, B: Luteoma, C: Papillary adenocarcinoma

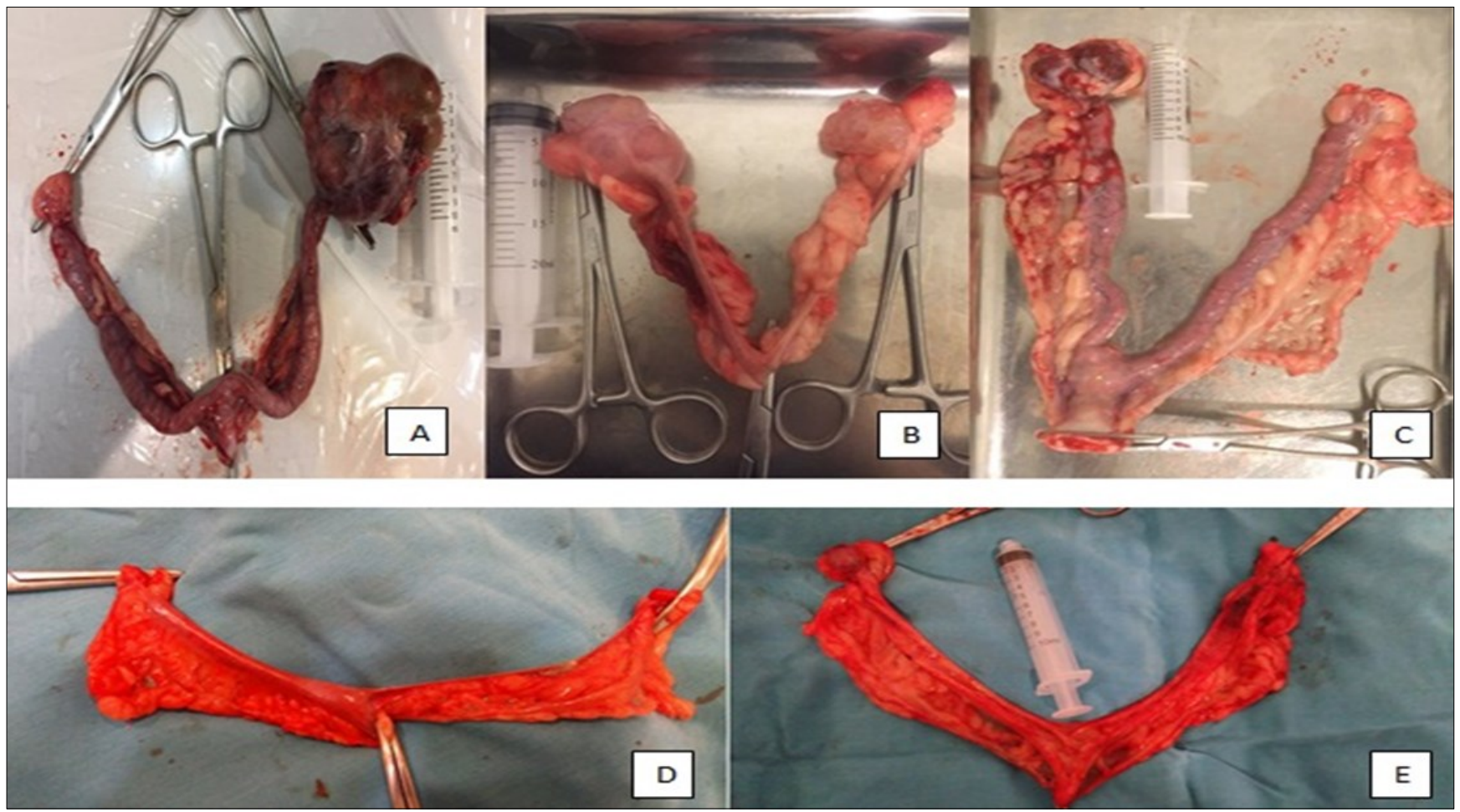

Figure 2. Macroscopic images of the genital tract with ovarian tumors after ovariohisterectomy section. A: Granulosa cell tumor B: Luteoma C: Papillary adenocarcinoma D: Adenoma E: Luteoma

affected ovaries in some of the bitches could be visualized macroscopically (Figure 2). Histopathological examination revealed one GCT, two luteoma, one papillary adenocarcinoma, two adenomas and one cystic papillary adenoma in group OT (Figure 3). Also subserosal localized tumor metastases on cervix uteri and cystic glandular hyperplasia in uterine horns were determined in the bitch with GCT. Five of seven bitches with ovarian tumors were in the dioestrus stage. The bitch with GCT which had vaginal bleeding for two months, was in oestrus stage. Six bitches were enrolled in group $\mathrm{H}$. The bitches in group $\mathrm{H}$ were in dioestrus $(\mathrm{n}=3)$ and anoestrus $(n=3)$.

The mean values and standard errors of RBC, HCT, HGB, WBC, PLT and PCT values in group OT and group $\mathrm{H}$ and their significances were presented in Table 1.

\section{Discussion}

Canine ovarian tumors are usually observed in older ages and affected animals vary from 5 to 15 years old (Sforna et al., 2003). The average age of the bitches in group OT were consistent with previous reports.

The researchers (Arlt and Haimerl, 2016) reviewed that ovarian cysts and ovarian neoplasia in female dogs regarding epidemiologic, clinical and fertility aspects. Ultrasonography is one of the diagnostic methods to reveal the pathologies in gynaecology. Ultrasonographic appearances of ovarian tumors have variable echogenicity. Structures of papillary adenocarcinomas in ovaries are usually solid or solid with cystic components (Diez-Bru et al., 1998). One of the malignant ovarian tumors in the presented study was papillary adenocarcinoma which had an anechogenic display in the ultrasonographic 
Table 1. Mean values and standard errors of complete blood count parameters and their significances related to groups

\begin{tabular}{lllcccc}
\hline & \multicolumn{1}{c}{ RBC } & HCT & HGB & WBC & PLT & PCT \\
& $\left(1 \times 10^{6} / \mu \mathrm{L}\right)$ & $(\%)$ & \multicolumn{1}{c}{$(\mathrm{g} / \mathrm{dL})$} & $\left(1 \times 10^{3} / \mu \mathrm{L}\right)$ & $\left(1 \times 10^{3} / \mu \mathrm{L}\right)$ & $(\%)$ \\
\hline Group OT & $5.76 \pm 0.41$ & $36.5 \pm 2.67$ & $12.7 \pm 0.96$ & $23.9 \pm 5.24$ & $741.3 \pm 83.11$ & $0.64 \pm 0.12$ \\
Group H & $7.11 \pm 0.26$ & $44.9 \pm 1.93$ & $15.7 \pm 0.64$ & $18.2 \pm 8.69$ & $373.3 \pm 43.07$ & $0.36 \pm 0.04$ \\
P values & $<0.05$ & $<0.05$ & $<0.05$ & NS & $<0.01$ & $=0.07$ \\
\hline
\end{tabular}

RBC: Red blood cell, HCT: Hematocrit, HGB: Hemoglobin, WBC: White blood cell, PLT: Platelet, PCT: Plateletcrit

examination due to the cystic structure, similar to the previous report (Diez-Bru et al., 1998). Even if GCT could occur in different animal species as queens (Günay Uçmak et al., 2018), mares (Kurban et al., 2019) and bitches, ultrasonographic images of GCTs appeared with similar characteristic. In line with the other researchers' reports (Günay Uçmak et al., 2018; Kurban et al., 2019), the ovary affected with GCT was massive, solid and multilobular structure that had a hypoechogenic display in transabdominal ultrasonography. Although the distant metastasized organ was different, similar to the researchers' statement (Günay Uçmak et al., 2018), GCT was metastasized in this research. A benign ovarian neoplasia that was visualized in ultrasonographic examination was diagnosed as luteoma following the histopathologic examination, in this study. Yılmaz et al. (2017) reported a case of unilateral luteoma in the ovary of a dog which was $13 \mathrm{~cm}$ in size. In ultrasonographically it appeared as a hypoechoic, round mass with homogeny architecture. Although contradictive results obtained in mass size, ultrasonographic data from to ovary with luteoma were similar to observation from Yılmaz et al. (2017). In addition to the ultrasonographic examination, $\mathrm{CBC}$ and thoracic radiographs should be performed for the diagnosis of ovarian neoplasms (McEntee, 2002). Anemia is the most common paraneoplastic syndrome from hematological indicators of neoplasms (Aydin et al., 2011). Due to increased estradiol secretion in granulosa cell tumors, non-regenerative anemia improves in the affected bitch (Nak et al., 2012). Although the bitches with benign ovarian neoplasms had mild anemia, decreased RBC, HCT and HGB levels were presented in group OT. Both the bitch with GCT and the bitch with papillary adenocarcinoma had severe anemia.

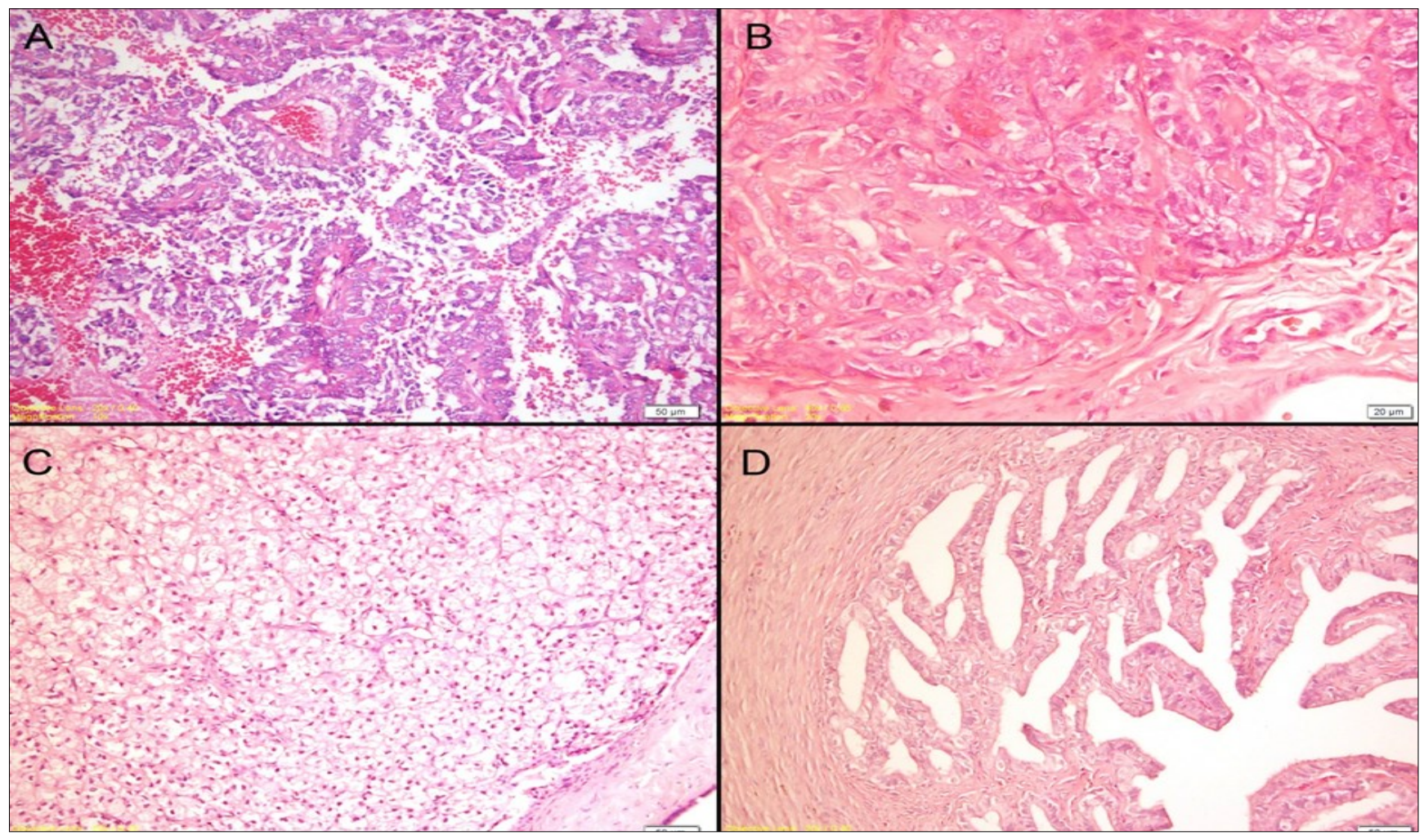

Figure 3. Histologic features of ovarian tumors. A: Granulosa cell tumor (HE, bar: $50 \mathrm{~mm}$ )

B: Papillary adenocarcinoma (HE, bar: $20 \mathrm{~mm}$ ). C: Luteoma (HE, bar: $50 \mathrm{~mm}$ ). D: Papillary adenoma (HE, bar: $50 \mathrm{~mm}$ ). 
The decline of RBC, HCT and HGB levels were supposed to be due to the malignant ovarian tumors. Oviedo-Penata et al. (2020) were determined normocytic normochromic anemia. The researchers (Oviedo-Penata et al., 2020) were reported that anemia was formed as a result of suppression of erythropoiesis due to the chronic condition in pyometra. As in the previous report, ovarian tumor (GCT) and pyometra existed together in one case of the presented study and the bitch had anemia. Consistent with the previous report (Oviedo-Penata et al., 2020), severe anemia was thought to exist due to the vaginal bleeding for two months that developed as a symptom of pyometra in the bitch with GCT. However, other reasons for normocytic and normochromic anemia are acute haemolysis, haemorrhagia, iron deficiency, chronic renal diseases, chronic inflammation and neoplasia (Arun 2013). In accordance with the previous statement, normocytic and normochromic anemia could exist due to presence of ovarian neoplasms in group OT.

Cancer progresses due to platelet activation and thrombotic complications (Li, 2016). A significant increase of PLT levels in group OT indicates the cancer progression, as noted in the previous report ( $\mathrm{Li}, 2016)$. The tendency of higher PCT and significant rise of PLT in group OT suggest that PLT and PCT are related to cancer progression notwithstanding histopathological character of the tumor. Platelet adhesions to cancer cells strongly contribute to metastasis via a hematogenous way (Honn et al., 1992). In contrast with Honn et al. (1992), although only one case in group OT had distant metastasis, PLT levels were significantly higher than group $\mathrm{H}$. However, group OT had both malignant and benign ovarian tumors. It was suggested that both malignant and benign ovarian tumors should be followed up in terms of distant metastasis.

In conclusion, the evaluation of complete blood count in bitches with ovarian tumor could be important to estimate the hematological effect of tumor progression.

\section{References}

Arlt, S. P., \& Haimerl, P. (2016). Cystic ovaries and ovarian neoplasia in the female dog- a systematic review. Reproduction in Domestic Animals, 51(1), 3-11.

Arun, S. S. (2013). Kan patolojisi, Retrieved from

https://cdn.istanbul.edu.tr/FileHandler2.ashx?f=kanhastaliklari-patolojisi1.pdf

Aydın, D., Olgun Erdikmen, D., Ülgen, S., Demirutku, A., \& Durmuş, D. (2011). Kedi ve Köpeklerde Paraneoplastik Sendromlar. Erciyes Üniversitesi Veteriner Fakültesi Dergisi, 8(2), 127-137.

Bertazzolo, W., Dell’orco, M., Bonfanti, U., Delorenzi, D.,
Masserdotti, C., De Marcos, B., Caniatti, M., \& Roccabianca, P. (2004). Cytological features of canine ovarian tumours: A Retrospective study of 19 cases. Journal of Small Animal Practice, 45, 539-545.

Diez-Bru, N., Garcia-Real, I., Martinez, E. M., Rollan, E., Mayenco, A., \& Llorens, P. (1998). Ultrasonographic appearence of ovarian tumors in 10 dogs. Veterinary Radiology and Ultrasound, 39(3), 226-233.

Gômez-Laguna, J., Millân, Y., Reymundo, C., Domingo, V., \& Martin de las Mulas, J. (2008). Bilateral retiform sertolileydig cell tumour in a bitch. Alpha-Inhibin and epitethelial membrane antigen as useful tools for differential diagnosis. Journal of Comparative Pathology, 139, 137-140.

Günay Uçmak, Z., Uçmak, M., Tek, Ç., Koenhemsi, L., Erdoğan Bamaç, O., Gürel, A., \& Yıldar, E. (2018). Granulosa cell tumor in a spayed young queen. Journal of the Hellenic Veterinary Medical Society, 69(2), 1010-1015.

Günay Uçmak, Z., \& Güvenç, K. (2019). Malign meme tümörlü dişi köpeklerde klinik ve bazı hematolojik parametreler arasındaki ilişkinin değerlendirilmesi. Türkiye Klinikleri Veteriner Bilimleri Dergisi,10(2), 45-52.

Honn, K. V., Tang, D. G., \& Crissman, J. D. (1992). Platelets and cancer metastasis: a causal relationship? Cancer and Metastasis Reviews, 11(3-4), 325-351.

Kurban, I., Günay Uçmak Z., Gündüz, M. C., Baykal, A., Sönmez, K., \& Gürel, A. (2019). A case of granulosa cell tumor in an Arabian mare. Türkiye Klinikleri Veteriner Bilimleri Dergisi, 10(1), 31-36.

Li N. (2016). Platelets in cancer metastasis: To help the "villain" to do evil. International Journal of Cancer, 138, 2078-2087.

McEntee, M. C. (2002). Reproductive oncology. Clinical Techniques in Small Animal Practice, 3, 133-149.

Nak, D., Alasonyalılar Demirer, A., Tuna, B., Nak, Y., \& Özyiğit, M. Ö. (2012). Vaginal prolapse related to ovarian granulosa cell tumor in an Anatolian Shepherd. Turkish Journal of Veterinary and Animal Science, 36(1), 61-66.

Namazi, F., Hasiri, M. A., Nikahval, B., Khafi, M. S. A., \& Kish, G. F. 2015. Clinicopathological and immunohistochemical characteristics of ovarian luteoma associated with endometrial hyperplasia in a bitch. Comparatice Clinical Pathology, 24, 705-707.

Nielsen, S. W., Misdorp, W., \& McEntee, K. (1976). Tumours of the ovary. Bulltein of the World Health Organization, 53(2-3), 203-215.

Oviedo-Penata, C., Hincapie, L., Riano-Benavides, \& C., Malsonado-Estrada, J. G. (2020). Concomitant presence of ovarian tumors (Teratoma and granulosa cell tumor), and pyometra in an English Bulldog female dog: A case report. Frontiers in Veterinary Science, 6, 500.

Sforna, M., Brachelente, C., Lepri, E., \& Mechelli, L. (2003). Canine ovarian tumours: A retrospective study of 49 cases. Veterinary Research Communications, 27(1), 359361.

Yılmaz, R., Özyiğit, M.Ö., \& Akkoç, A. (2017). Bir köpekte tek taraflı luteoma olgusu. Uludag Universitesi Veteriner Fakültesi Dergisi, 36(1,2), 33-35. 